\section{Need Analysis of English Material for Vocational School of Health: A Case Study at One School at Karanganyar}

\author{
1 Phoumchay Vongvilay \\ 2 Dwi Kartika \\ 3 Malikatul Laila
}

123 Universitas Muhammadiyah Surakarta, Indonesia

\begin{abstract}
This research aims to identify the students' prospective professional need in learning English writing skills, to identify the style of learning that students preferred in learning English writing skills, and to reveal the incompetent that students need to improve in writing. This study required stratification that minimizes sampling errors to zero level. In this study, the 140 students from the second grade were chosen to be the participant. The questionnaire was used to be instruments to get the responses from the students about the learning needs. This study found that students need writing sentences correctly in learning English writing. The style of learning that students needed to learn English writing skills was in a small group more than group work. The topic that students preferred in learning is the topic about health as their background school is health, nursing, and pharmacy program. Students actually needed to learn English by themselves. The idea expansion was incompetent that students need to improve in writing. It is hoped that all these needs analyzed can be taken into attentiveness in increasing an ESP course for students.
\end{abstract}

\section{Keywords}

teaching ESP

students' need analysis

learning need

\section{Ethical Lingua}

Vol. 7, No. 2, 2020

ISSN 2355-3448 (Print)

ISSN 2540-9190 (Online)

Corresponding Email

Phoumchay Vongvilay

S400190006@student.ums.ac.id

Article's History

Submitted 16 June 2020

Revised 11 August 2020

Accepted 17 September 2020

DOI

10.30605/25409190.186

Copyright $\odot 2020$

The Author(s)

This article is licensed under CC BY-NC-SA 4.0 License

\section{(cc) BY-NC-SA}




\section{Need Analysis of English Material for Vocational School of Health: A Case Study at One School at Karanganyar}

Nowadays, teaching material is one of the most important aspects of teaching and learning. Informative (informs the learner about the target language), instructional (guides the learner in practicing the language), experiential (provides the learner with experience of the language in use), eliciting (encourages the learner to use the language), and exploratory (helps the learner to make discoveries about the language) have been good teaching material (Tomlinson, 2003. P 143). Because of the ideal materials aim to provide the learners with all these ways of acquiring a language. So, different learners study in different ways. Whatever the reality is that the most commercially produced materials focus only on informing their users about language features and guiding them to practice them. Richards \& Renandya (2002) has commented that instructional materials generally serve as the basis of much of the language input that learners receive and the language practice in the classroom. For this reason, to achieve the intended characteristics, teaching materials should be well developed by considering the context and the needs of the users.

Need analysis is the cornerstone of ESP that leads to a very focused course (Dudley-Evans \& St. John, 1998. p 128-45). It could be seen as a process to assess students' communicative needs in order to achieve specific learning objectives. The aim of need analysis is to collect the information concerning students in order to define the target situation and environment of studying ESP (Otilia, 2015. p 54-55). As the instrument to establish how and what the learning process will be held, need analysis covers many aspects of teaching and learning process, including students' background, students' current language proficiency, students' purpose in learning English, etc.

Learning needs manages with the needs of the individuals since they have learned. This need will be stimulated for individuals to learn continuously. The basic human needs have been from the lowest level to the highest level. It is called the human needs level. Otherwise, every situation it is less than it should be designated a "need." whether the gap is large or causes consequences, it is necessary to place as a priority that must be overcome.

The learning needs differ from one another, which means everyone criticizes to have different learning needs. Therefore, the learning needs need by someone in the country may be different from the learning needs of people living in urban areas. The comprehended need for learning last year may also be different from the comprehended learning needs in the future. Whether a learning need has been met, and then the other learning needs that have to be met through the learning activities must also be met. So, the learning needs should be identified through an individual approach.

Needs are the everlasting tendencies that exist within a person's motivation to achieve a certain goal. The learning need is significant to predicate as the foundation for the preparation of the learning program. The needs for learning that have been predicated will supply direction where the program activities are addressed. It is compulsory for the reason that the learning need is the basis that describes the distance between the learning purposes wanted by the learners or the actual learning conditions. Each learner has different needs that should be 
identified to determine what needs the learner will have in potential and eventually become his needs.

Moreover, the need for learning is a contemporary learner's competence correlated with the competence of learners who should be mastered. The distinctness includes knowledge, skill, and attitude. For the reason that the potentials that exist in each learner will be indicated according to their individual learning needs. So, in the implementation of the learning needs, the involvement of learners is needed. The needs for learning will be organized carefully and sequentially, then determined by the priority of learning needs or basic interests to be fulfilled through the learning activities.

According to Barnard \& Zemach (2003. p 306-323) state that ESP is one of English teaching areas that can be seen as the selection of teaching content and approach according to perceived needs of the students (Tomlinson, 2003. p 306). The focused of ESP on English teaching and learning process is related to the particular job or study-related cause. Besides that, English for Academic Purposes (EAP), as a branch of ESP, also provides students with proper English skills that are needed in a tertiary level study or college level, including the way of presenting, researching, and publishing in academic field. The knowing and understanding about the genre have been the key elements in all communication including in writing for academic purposes. It interlaces the understanding of the intentions of the discourse community that reads the text and of the agreements related with structure, the language and the oratory of the genre (Dudley-Evans \& St John, 1998. p 128-45).

In the area of English Academic Purposes, the students' competence in writing for academic purposes required not only in the college standardized system of communication but also as an essential tool for students in constructing new knowledge. It also can be seen as a means to know students' competency, students' personal interests, and academic performance. Moreover, writing can be seen as the result of thinking, concept development, and revision. It requires special skills to explore writers' ideas to be presented and to be understood.

Instructional material context involves consideration of some criteria: 1) aims and approach: It relates to a degree of correspondence to the students' needs; 2) bibliographic features: It shows the quality and availability of the package; 3 ) design: It shows the attractiveness of the layout, visual appeal, readability and instructions clarity; 4) organization: This relates to sequencing and progression of suitable exercises, units, and proficiency level; 5) content: It shows a degree of authenticity, relevance, and appropriacy of the text genres; 6) methodology: It will extend to which tasks, exercises, and methods which are appropriate to students' proficient and goals; 7) usability: This relates to flexibility, completeness, and feasibility of the materials; and 8) overall: It relates to the general quality of the text and its suitability for the purpose. The context of the instructional material can be a consideration in determining the suitability between its role, orientation, and students' needs. The instructional material of writing skills for academic purposes should be tailored based on students' needs and learning objectives.

In selecting the instructional material of writing skills for academic purposes, there are some requirements that should be considered; 1) the topic should make the students interested, the acceptable of culture, and in line with the learning objectives; 2) the expected type of writing; 3 ) the methods of generating ideas, whether through brainstorming, free-writing, listing, mapping, outlining which are appropriate for the students; 4) the instruction for writing that will help the students to organize the various types of writing, such as narration, letters, exposition, description, arguments and what students need to be practiced; 5) opportunities 
to collaborate in writing; 6) opportunities to revise which encourage students to do the various stages in writing process; 7) instruction in proofreading and editing. What students study concerning with finding and editing their errors in writing (Richards \& Renandya, 2002. p 311312). Instructional material plays a very special role in constructing students' knowledge and understanding by providing much access to specialized knowledge and skills. It can be a source to help the students to construct the mental representation, including writing skill for academic purposes.

In assessing the students' specific needs we come across the term "needs analysis" which has been different along the decades. At the initial stages of ESP (the 1960s and early 1970), needs analysis consisted in assessing the communicative needs of the learners and the techniques of achieving specific teaching objectives. The tasks of needs analysis is much more complex: it means that collecting information about the students and at defining the target situation and environment of studying ESP. Based on Duddley-Evans and St. John (2009) there are eight components in today concept of needs analysis which have been grouped into five broad areas including: 1. target situation analysis and objective needs analysis (e.g. tasks and activities learners will use English for; 2. linguistic analysis, discourse analysis, genre analysis, i.e. knowledge of how language and skills are used in the target situations; 3. subjective needs analysis, i.e. learners' wants, means, subjective needs-factors that affect the way they learn (e.g. previous learning experiences, reasons for attending the course, expectations); 4. present situation analysis for the purpose of identifying learners' current skills and language use; 5 . means analysis (e.g. information about the environment where the course will occur).

Based on the observation, it was found that the writing skill instructional materials for the academic purposes have not been designed and developed based on students' needs. Need analysis have not been implemented. It causes students having low performance in writing skill for academic purposes. Most of them did not have any motivation to be involved and to be active in class since they did not understand the essence of presented materials.

In writing skills, the students are precariously weak and substandard. The majority problem is due to incompetence in syntax, coherence, idea expansion, content selection, topic sentence, rhetorical conventions, mechanics, organization, lack of vocabulary, inappropriate use of vocabulary (Fareed, Ashraf, \& Bilal, 2016. p 81-92). That condition can be solved through the suitable instructional material use as one of the learning sources.

Sumarsono, Bagis, \& Arrafii's (2017) study found the objectives of the writing courses were appropriate to the students' needs. However, the courses did not accommodate the realization of the goals/objectives. The approaches/ methodology, to some degree, were not contextual and did not meet the needs of the students. The classroom management, to some extent, was not effective, and the class/program resources, for certain aspects, were adequate to implement the goals/objectives of the courses. In addition to that, a study by Tenri Ampa \& Quraisy (2018) found the learning needs for the writing skills coped with the types of paragraph development, the types of text, and components of writing skill. The implication of the findings would be the base of teaching and learning process, especially in designing the learning materials for the English writing skill. In addition to that, Tjalla, Akil, Hamra, \& Haryanto's (2015) study found students have been familiar with writing activities doing outside the classroom such as write SMS, write in diary, write literary works such poem, short story, etc. 
This current study explores the students' prospective professional need in learning English writing skill, to identify in term of style of learning that students preferred in learning English writing skills and to reveal the incompetent that students' need to improve in writing. It brought the basic information as further inquiry and suitable solution in developing instructional material, especially in writing skills for academic purposes.

\section{Method}

The research aimed to identify the students' prospective professional need in learning English writing skill, to identify style of learning that students preferred in learning English writing skills and to reveal the incompetent that students' need to improve in writing. In this study, the 140 students from second grade were chosen to be the participant. The sample of the study were chosen randomly. It requires stratification that minimizes sampling errors to zero level (Alastal \& Shuib, 2012; Long, 2005). The questionnaire was used to be instruments to get the responses from the students about the learning needs. The process to collecting data were: (1) identifying and scoring the students' responses; (2) making students' responses percentage; (3, ranking the students' responses percentage; (4) deciding the students' needs level.

\section{Results}

The research aimed to identify the students' prospective professional need in learning English writing skill, to identify in term of style of learning that students preferred in learning English writing skills and to reveal the incompetent that students' need to improve in writing. This section presents the result of the research.

The data in table (1) covered the students' prospective professional need in learning English writing. The most students answered that the prospective professional need in learning English writing is writing sentences correctly covered $59.29 \%$. While $10 \%$ is developing idea, $9.29 \%$ they answered that the prospective professional need in learning English writing is writing well-structured paragraphs. Moreover, they answered that the prospective professional need in writing is evaluating and revising writing and using correct punctuation and spelling. It is concluded that the prospective professional need in writing is writing correct sentences.

Table 1. Students' prospective professional need in learning English writing.

\begin{tabular}{llll}
\hline No & Response & Amount & Percentage (\%) \\
\hline 1 & Writing sentences correctly & 83 & 59,29 \\
\hline 2 & Writing well-structured paragraphs & 13 & 9,29 \\
\hline 3 & Writing research or report & 4 & 2,86 \\
\hline 4 & Writing summary and paraphrasing & 4 & 2,86 \\
\hline 5 & Organizing and planning writing & 8 & 5,71 \\
\hline 6 & Developing ideas & 14 & 10,00 \\
\hline 7 & Using correct punctuation and spelling & 2 & 1,43 \\
\hline 8 & Using appropriate vocabulary & 2 & 1,43 \\
\hline 9 & Evaluating and revising writing & 10 & 7,14 \\
\hline Total & & 140 & 100 \\
\hline
\end{tabular}

Hutchinson \& Waters (1987: 56) propose that the needs might differ form needs and contradict with the other stakeholders' perception. This is a demonstration which students 
were conscious of the skills that importance for the academic study purpose for the reason that the generality of the technical books wrote their discipline in English. The skill of English Writing was very predominant as well since students' graduation projects and Master's thesis was written in English. The intensive training was prescribed on these two skills. Not only to reveal the difficulty in discovering need of students, they might be focused in other skills "delayed needs rather than immediate needs when students would like to read" (DudleyEvans \& St. John, 1998. p 40).

Table 2. The topic that students preferred in Learning

\begin{tabular}{llll}
\hline No & Response & Amount & Percentage $(\%)$ \\
\hline 1 & Education & 49 & 35,00 \\
\hline 2 & Health & 60 & 42,86 \\
\hline 3 & Science and Technology & 7 & 5,00 \\
\hline 4 & Environment & 6 & 4,29 \\
\hline 5 & Language learning & 16 & 11,43 \\
\hline 6 & Religion & 2 & 1,43 \\
\hline Total & & 140 & 100 \\
\hline
\end{tabular}

The data from the table (2) showed that the response the topic that students preferred in learning. According to Nunan (2004. p 47) explained the spoken, written or visual data which learners work with in the completing course task. The result showed that most students answered that they prefer in the topic about health covered $42.86 \%$. it's because their background school is health, nursing, and pharmacy program. Some students answered that they prefer in the topic about education covered $35 \%$. They also answered language learning, science and technology, and religion topic.

Learning needs is mentions to students need doing in arrangement for learning the language. As stated by Hutchinson \& Waters (1987. p 61), a controlling needs analysis ought to supply for students' preference to learn and the learning condition. Therefore, the questionnaire of students enclosed needs of learning. Table (3) showed that the most students answered that Style of learning that they prefer in performing activities in small groups covered $32.14 \%$. The atmosphere of learning is convenient extremely in large classes since it approves big numbers of students to practice the language concomitantly and some students learn from each other.

Table 3. Style of learning that students preferred in learning English writing skills

\begin{tabular}{llll}
\hline No & Response & Amount & Percentage (\%) \\
\hline 1 & Individually & 29 & 20,71 \\
\hline 2 & In pairs & 10 & 7,14 \\
\hline 3 & In small groups & 45 & 32,14 \\
\hline 4 & As a class & 17 & 12,14 \\
\hline 5 & All the above & 39 & 27,86 \\
\hline & Total & 140 & 100 \\
\hline
\end{tabular}

Furthermore, work in group can be decreased teacher talk time and increased students talk time too. It can also be expressed that students need this learning atmosphere type in their field guide of teacher. Some students answered that they prefer in performing activities by individually covered $20.71 \%$, in pairs covered $7.14 \%$ and as a class covered $12.14 \%$. The students also answered that they prefer all about activities that mention in questionnaire covered $27.86 \%$. It is concluded that style of learning that students needed to prefer in learning is by themselves more than work with friends. 
Table 4. The incompetent that students' need to improve in writing

\begin{tabular}{llll}
\hline No & Response & Amount & Percentage (\%) \\
\hline 1 & Words Organization & 56 & 40,00 \\
\hline 2 & Idea expansion & 79 & 56,43 \\
\hline 3 & lack of vocabulary & 3 & 2,14 \\
\hline 4 & Inappropriate use of vocabulary & 2 & 1,43 \\
\hline Total & & 140 & 100 \\
\hline
\end{tabular}

The table (4) above showed about the incompetent that students' need to improve in writing, it can be seen that $56.43 \%$ of the participants they needed to improve the idea expansion. They also needed to improve the incompetent in writing with words organization covered $40 \%$. They also answered that incompetent that students' need to improve in writing are lack of vocabulary and inappropriate use of vocabulary.

From the result of questionnaire, they answered that they studied harder; they understand words or sentences in English with a lot of reading and not being read in a passionate way of writing learning, understand in more detail and learn more, and does not limit the imagination. Another participants also mentioned that they improved their English writing by reading and understanding more each reading that they will write; by finding material from the internet and by helping each other between friends if there are difficulties. They also answered that they improved their writing with a learning vocabulary and keep repeating until memorized, writing well structured paragraphs and many others. Moreover, they also answered that they were active in learning to write and read and memorize; view the improvement of writing, and started from recognizing the aspects covered to be able to make an English writing. They also answered that they improve by continuing to practice by writing and repeating the writing such as writing reports, writing notes, and writing.

Furthermore, the result from questionnaires also covered the suggestion new techniques to improve students' writing skills, students improve the skills possessed such as better understanding the meaning of each word, using the correct spelling and being able to express their ideas and made as a hobby to produce writings that are very good and can be understood by many people; They used a rubber grip for starters and just practice writing. some participants mentioned that they have paid attention to better and more correct writing. Moreover, they also answered that techniques to improve their writing they do an evaluation every after finished writing and ask the readers for suggestions and critics. Students also suggested should always respect and support the results of writing; practiced with easy vocabulary that goes to hard, communication via WhatsApp but using English and studied hard to write with interesting summaries and summarize simply.

\section{Discussion}

Need analysis is important to increase in the class because that teacher will have known students' need when teaching. This research reveals that writing sentences correctly is students' prospective professional need in learning English writing. Students needed to write in sentences correctly when they make the paragraph. Besides that, developing idea and writing well-structured paragraphs also is needed for the prospective professional need in learning English writing. Moreover, they also needed for evaluating and revising writing and using correct punctuation and spelling for prospective professional need in writing it is concluded that the prospective professional need in writing is writing sentences correctly. 
Unlike Tenri Ampa \& Quraisy's (2018) study, this study reveals the learning needs for the writing skills coped with the types of paragraph development, the types of text, and components of writing skill. The implication of the findings would be the base of teaching and learning process, especially in designing the learning materials for the English writing skill.

From the result the topic is about health that the most students prefer in learning because their background school is health, nursing, and pharmacy program. Some students needed to learn in topic about education, language learning, science and technology, and religion topic.

The present analysis showed that the style of learning that they needed to perform activities in small groups. The atmosphere of learning is convenient extremely in large classes since it approves big numbers of students to practice the language concomitantly and some students learn from each other. Furthermore, work in group can be decreased teacher talk time and increased students talk time too. It can also be expressed that students need this learning atmosphere type in their field guide of teacher. Some students needed performing activities by individually, in pairs and as a class. This is in line with Tjalla, Akil, Hamra, \& Haryanto's (2015) study, which found that students have been familiar with writing activities doing outside the classroom such as write SMS, write in diary, write literary works such poem, short story, etc.

Form the result showed that the incompetent that students' need to improve in writing, it can be seen that $56.43 \%$ of the participants they needed to improve the idea expansion. They also needed to improve the incompetent in writing with words organization. They also need to improve the incompetent in writing with lack of vocabulary and inappropriate use of vocabulary. This is in line with Fareed, Ashraf, \& Bilal's (2016) study, which shows that in writing skills the students are precariously weak and substandard. The majority problem is due to incompetence in syntax, coherence, idea expansion, content selection, topic sentence, rhetorical conventions, mechanics, organization, lack of vocabulary, inappropriate use of vocabulary. That condition can be solved through the suitable instructional material use as one of the learning sources.

\section{Conclusion}

The objectives of this research are to identify the students' prospective professional need in learning English writing skill, to identify in term of style of learning that students preferred in learning English writing skills, and to reveal the difficulties that students' need to improve in writing. The researchers conclude that the need analysis of English material for Vocational School of Health following as students' prospective professional need in learning English writing is writing sentences correctly. The topic that students preferred in learning is topic about health. The style of students at Vocational School of Health prefer in performing activities in small groups. Students actually needed depending to learn English by themselves. The incompetent that students' need to improve in writing is the idea expansion. It is hoped that all these needs analyzed can be taken into attentiveness in increasing an ESP course.

\section{Acknowledgment}

Many colleagues, students and lecturer have contributed to this research. To all of them, thank you. The researchers would like to thank our families for their much appreciated 
encouragement and support throughout the composition and revision of the manuscript that eventually turned into this research.

\section{References}

Barnard, R., \& Zemach.,D. (2003). Materials for specific purposes. In B. Tomlinson (Ed.), Developing Materials for Language Teaching (pp. 306-323). London/New York: Continuum.

Dudley-Evans, T., \& St John, M. (1998). Developments in ESP: A Multi-Disciplinary Approach. Cambridge: Cambridge University Press.

Hutchinson, T., \& Waters, A. (1987). English for Specific Purposes: A Learner-Centered Approach. Cambridge: Cambridge University Press. https://doi.org/10.1017/CB09780511733031

Fareed, M., Ashraf, A., \& Bilal, M. (2016). ESL Learners' Writing Skills: Problems, Factors and Suggestions. Journal of Education \& Social Sciences, 4(2), 83-94. https://doi.org/10.20547/jess0421604201

Richards, J. C., \& Renandya, W. A. (Eds.). (2002). Methodology in Language Teaching: An Anthology of Current Practice. Cambridge University Press.

Otilia, S. M. (2015). NEEDS ANALYSIS IN ENGLISH FOR SPECIFIC PURPOSES. Annals Economy Series, 1II, 54-55. Retrieved from https://econpapers.repec.org/RePEc:cbu:jrnlec:y:2015:v:1ii:p:54-55

Sumarsono, D., Bagis, A., \& Arrafii, M. (2017). Students' Needs to Develop English Writing Materials. Lingua Cultura, 11(2), 67-71. https://doi.org/10.21512/lc.v11i2.1504

Tenri Ampa, A., \& Quraisy, H. (2018). Needs Analysis of the English Writing Skill as the Base to Design the Learning Materials. SHS Web of Conferences, 42, 00050. https://doi.org/10.1051/shsconf/20184200050

Tjalla, M., Akil, M., Hamra, A., \& Haryanto. (2015). The Analysis of EFL Students? Needs for Writing Materials Development. International Journal of Science and Research (IJSR), 6(8). 313-317. https://www.ijsr.net/get_abstract.php?paper_id=ART20175922

Tomlinson, B. (2003). Developing Principled Frameworks for Materials Development. In B. Tomlinson (Ed.), Developing Materials for Language Teaching (pp. 107-129). London/New York: Continuum. 